\title{
Surface treatment by plasma carbonitriding of Ti-6AI-4V alloy for dental implants
}

\section{Tratamento de superfície por carbonitretação a plasma de liga de Ti-6Al-4V para implantes dentários}

\author{
Jailson de Jesus*1 ${ }^{* 1}$ Enori Gemelli ${ }^{1}$, Fábio Nery' ${ }^{1}$, Luís César Fontana ${ }^{2}$, Nelson Heriberto Almeida Camargo
}

\begin{abstract}
In recent years, intensive development of dentistry stimulates the demand for new titanium implant materials created by surface engineering. Plasma nitriding is proposed as a solution to improve the biocompatibility. This work investigated the influence of plasma carbonitriding on the roughness and contact angle of Ti6Al4V treated in a $\mathrm{Ar} / \mathrm{N}_{2} / \mathrm{CH}_{4}$ plasma for $3 \mathrm{~h}$ and $6 \mathrm{~h}$ at $600^{\circ} \mathrm{C}$. The characterization was made by $X$-ray diffraction (XRD), field emission scanning electron microscopy (FE-SEM), Theta Lite Optical Tensiometer, and laser confocal microscopy. The XRD results indicated the formation of $\mathrm{Ti}_{3} \mathrm{~N}_{1.29}$ and $\mathrm{Ti}_{2} \mathrm{~N}$ phase. It was observed that the surface roughness increases from 0.24 to $0.87 \mu \mathrm{m}$ after $3 \mathrm{~h}$ and from 0.24 to $1.09 \mu \mathrm{m}$ after $6 \mathrm{~h}$ of carbonitriding. The contact angle was $38^{\circ}$ and $30^{\circ}$ for $3 \mathrm{~h}$ and $6 \mathrm{~h}$, respectively.
\end{abstract}

Keywords: Ti-6Al-4V, Plasma carbonitriding, Dental implants.

\section{RESUMO}

Nos últimos anos, o desenvolvimento intensivo de odontologia tem estimulado a demanda por novos materiais de implante de titânio criados por engenharia de superfícies. A nitretação a plasma é proposta como uma solução para melhorar a biocompatibilidade. Este trabalho investigou a influência de carbonitretação por plasma na rugosidade e no ângulo de contato da liga de Ti6Al4V tratado em um plasma $\operatorname{Ar} / \mathrm{N}_{2} / \mathrm{CH}_{4}$ por $3 \mathrm{~h} \mathrm{e} 6 \mathrm{~h} \mathrm{a} 600^{\circ} \mathrm{C}$. A caracterização foi feita por difração de raios-X (DRX), microscopia eletrônica de varredura por emissão de campo (EC-MEV), tensiometro ótico Theta Lite e microscopia confocal a laser. Os resultados de DRX indicaram a formação das fases $\mathrm{Ti}_{3} \mathrm{~N}_{1.29}$ e Ti $\mathrm{T}_{2} \mathrm{~N}$. Foram observados aumentos de rugosidade de superfície de 0,24 para 0,87 $\mu \mathrm{m}$ após $3 \mathrm{~h}$ de carbonitretação e de 0,24 para $1,09 \mu \mathrm{m}$ após $6 \mathrm{~h}$. O ângulo de contato foi de $38^{\circ}$ e $30^{\circ}$ para $3 \mathrm{~h} \mathrm{e} 6 \mathrm{~h}$ respectivamente.

Palavras-chave: Ti-6Al-4V, Carbonitretação a plasma, Implantes dentários.

1Universidade do Estado de Santa Catarina - Programa de Pós-Graduação em Ciência e Engenharia de Materiais - Departamento de Engenharia Mecânica - Joinville/SC - Brazil.

${ }^{2}$ Universidade do Estado de Santa Catarina - Programa de Pós-Graduação em Ciência e Engenharia de Materiais - Department de Física - Joinville/SC Brazil.

Correspondence author: Jailson de Jesus | Universidade do Estado de Santa Catarina - Programa de Pós-Graduação em Ciência e Engenharia de Materiais Departamento de Engenharia Mecânica | Campus Universitário, Bom Retiro, CP 631 | CEP 89.223-100 - Joinville/SC - Brazil |E-mail: nosliaj@gmail.com Received: Feb. 24, 2015 Approved: Jan. 12, 2018 


\section{INTRODUCTION}

Titanium and its alloys, especially Ti6Al4V, have been widely used in the manufacturing of dental implants because of their superior mechanical property, low density, high corrosion resistance and excellent biocompatibility ${ }^{1,2}$. However, in recent years intensive development of dentistry stimulates the demand for new titanium implant materials created by surface engineering ${ }^{3}$.

Properties such as roughness and contact angle are important for cell growth and proliferation, helping to establish the implant. Several studies have shown that increasing in surface micro- and submicron-scale roughness, with feature sizes comparable to cell dimensions, lead to enhanced osteoblast differentiation and local factor production in vitro ${ }^{4,5}$, increased bone-to-implant contact in vivo ${ }^{6,7}$ and improved clinical rates of wound healing ${ }^{8,9}$. Surface nano-scale roughness, which directly corresponds to the sizes of proteins and cell membrane receptors ${ }^{10}$, recently added to the surface of implants to better mimic the hierarchical structure of bone, has also shown promising results in vitro ${ }^{11}$, in vivo ${ }^{12}$ and in the clinic $^{13,14}$, validating the biological relevance of nanotopography for bone formation.

The surface energy of an implant, measured indirectly by the liquid-solid contact angle (CA) and thus related to wettability, is another surface characteristic known to affect the biological response to the implant. Surface wettability can affect four major aspects of the biological system: (i) adhesion of proteins and other macromolecules onto the surface (conditioning); (ii) hard and soft tissue cell interactions with the preconditioned surfaces; (iii) bacterial adhesion and subsequent bio-film formation; and (iv) rate of osseous integration in the clinic (in vivo) ${ }^{15}$. The lower the contact angle, the better wettability of biological fluids on the surfaces of implants.

Plasma surface modification is an effective and economical surface treatment technique for many materials and has aroused growing interests in biomedical engineering ${ }^{16}$. Plasma nitriding has been proposed as a possibility for improving the surface properties ${ }^{17}$. Plasma nitriding of titanium alloys results in a thin composed layer of titanium nitrides, and a nitrogen diffusion $z^{2} e^{18}$. Titanium nitride has been successfully used as coating materials due to their tribological properties, biocompatibility and affordable price ${ }^{19}$. In this work, the plasma was generated from the atmosphere $0.49 \mathrm{~N}_{2} / 0.49 \mathrm{Ar} / 0.02 \mathrm{CH}_{4}$. Ions of $\mathrm{Ar}(40 \mathrm{amu})$ are efficient for sputtering of $\mathrm{Ti}(47.9 \mathrm{amu})$ due their similar atomic mass. Therefore, the bombardment of $\mathrm{Ar}^{+}$on the $\mathrm{Ti}$ surface can produce high surface roughness that is the aim of this work. It is inexorable in plasma nitriding process the presence of residual gas in the vacuum chamber, like $\mathrm{O}_{2}$ and $\mathrm{H}_{2} \mathrm{O}$, which can oxidize the surface a material to be treated. For minimizing this possible oxidation, we used a low proportion of $\mathrm{CH}_{4}$ in the plasma atmosphere (associated with the ion bombardment during the plasma nitriding) that contributes to a lower oxidation state of the Ti surface ${ }^{20}$.

The aim of this work is to study the surface changes of Ti6Al4V caused by the plasma carbonitriding for biomedical applications, evaluating the behavior of roughness and wettability properties as well as morphology generated by the intense plasma ion bombardment.

\section{MATERIALS AND PROCEDURES}

Twenty discs machined from titanium grade 5 (Ti6Al4V) with dimensions of $6 \mathrm{~mm} \times 3 \mathrm{~mm}$ (diameter $\times$ thickness) were divided into two groups of ten samples. Table 1 shows the treatment parameters used in this work.

The equipment used for the treatment of nitriding consists of: a reactor (discharge chamber) made of stainless steel with $300 \mathrm{~mm}$ in diameter and $300 \mathrm{~mm}$ in length; an Edwards mechanical vacuum pump with a capacity of $18 \mathrm{~m}^{3} / \mathrm{h}$ was connected to the reactor, which is responsible for producing a vacuum of the order of $10^{-3}$ torr; gas cylinders $\mathrm{CH}_{4}, \mathrm{~N}_{2}$ and Ar; flowmeters for controlling the chemical composition of the gas mixture; a DC power supply; and pressure and temperature gauges.

The crystalline phases were characterized by using a $\mathrm{Cu} \mathrm{K}$-a Shimadzu XRD - 600 diffractometer ( 2 deg. / min, q - 2q) range from $20^{\circ}$ to $80^{\circ}$. The surface morphology was evaluated by field emission scanning electron microscopy (FE-SEM) model JSM-6701 F. Samples' contact angle, using water as a probe liquid, were measured using a contact angle detection system (Theta Lite Optical Tensiometer, KSV model CAM 101). The droplet images of de-ionized water ( $2 \mu \mathrm{l})$ on the sample surface were captured within $20 \mathrm{~s}$ after supplying water. The roughness parameters $\mathrm{Ra}$ and Sa samples were determined using a laser confocal microscope Leica Model DCM3D.

\section{RESULTS AND DISCUSSIONS $\mathrm{XRD}$ results}

Figure 1 shows $\mathrm{X}$-ray diffraction spectra recorded for untreated samples (Ti-6Al-4V) and carbonitrided during $3 \mathrm{~h}$ (N49_3) and 6 hours (N49_6). The XRD pattern for the as-received material was fitted with the hexagonal a-Ti and the cubic b-Ti phases ${ }^{21}$. The diffraction patterns for samples submitted to $3 \mathrm{~h}$ and $6 \mathrm{~h}$ of nitriding showed peaks corresponding to $\mathrm{Ti}_{3} \mathrm{~N}_{1.29}$ and $\mathrm{Ti}_{2} \mathrm{~N}$ phases, respectively.

Table 1:Treatment carbonitriding parameters.

\begin{tabular}{c|c|c|c|c|c|}
\hline $\begin{array}{c}\text { Samples } \\
\text { group }\end{array}$ & $\begin{array}{c}\text { Carbonitriding time } \\
\text { (h) }\end{array}$ & $\begin{array}{c}\text { Temperature } \\
\text { of treatment }\left({ }^{\circ} \mathbf{C}\right)\end{array}$ & $\begin{array}{c}\text { Plasma } \\
\text { Atmosphere }\end{array}$ & $\begin{array}{c}\text { Current of discharge } \\
\text { (A) }\end{array}$ \\
\hline 1 & 3 & 600 & $49 \% \mathrm{~N}_{2}, 49 \% \mathrm{Ar}, 2 \% \mathrm{CH}_{4}$ & 1.0 \\
\hline 2 & 6 & & 700 \\
\hline
\end{tabular}




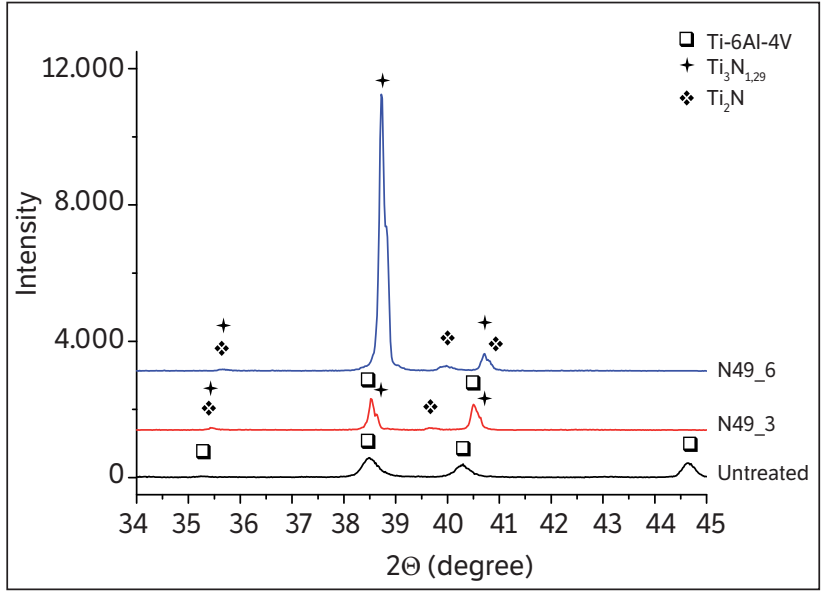

Figure 1: XRD of samples: untreated, N49_3 and N49_6.

\section{Surface morphology}

Figure 2 shows the FE-SEM analysis of (untreated) samples, where it is possible to see the scratches and grooves on the surface due to the machining process.

Figure 3 shows the morphologies of the samples submitted to carbonitriding. Figures $3 \mathrm{a}$ and $3 \mathrm{~b}$ show two magnification of a sample treated for $3 \mathrm{~h}$. It is possible to see deep nano-holes associated to high micro-roughness morphology. Figures $3 \mathrm{c}$ and $3 \mathrm{~d}$ show two magnification of a sample treated for $6 \mathrm{~h}$. It is possible to see higher micro-roughness morphology and more deep holes, indicating that the time of treatment is a very important parameter for changing the surface roughness. The morphology of the nitrided surfaces showed rosettes structures, generated by the action of the ion bombardment (mainly due to the argon ions that have the atomic mass closed to the Ti mass). The mixture of

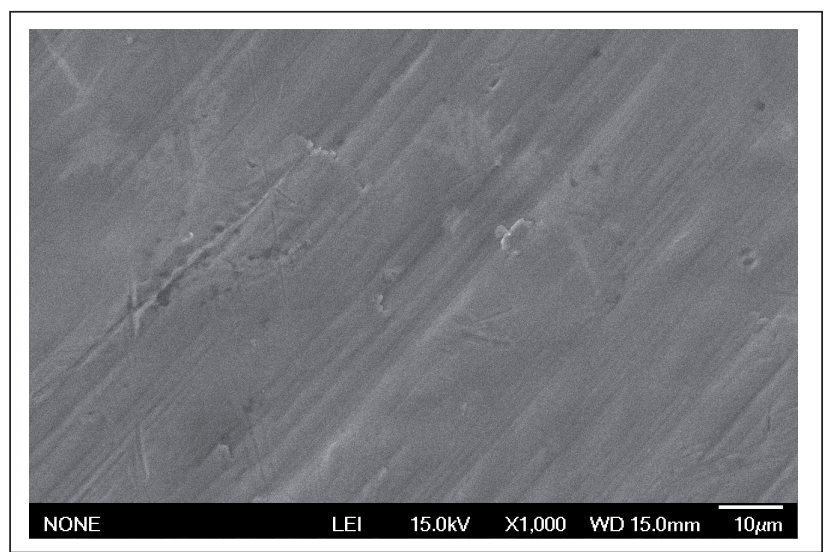

Figure 2: FE-SEM image of machined sample [1000 $\times]$. micro and nano-topography is excellent for the healing process. The nano-holes promote initial anchor of proteins that form the fibrin network by which cells migrate to the implant surface, while the micro-topography promotes adhesion of osteoblastic cells and stimulates cell differentiation that will result in the production of the new array bone ${ }^{22}$.

\section{Roughness}

The roughness of the machined samples showed mean values 0.23 and $0.24 \mu \mathrm{m}$ of $\mathrm{Ra}$ and Sa, respectively. The carbonitriding acted increasing the surface roughness depending on the time of treatment. Samples treated for $3 \mathrm{~h}$ showed $\mathrm{Ra} 0.91 \mu \mathrm{m}$ and $\mathrm{Sa}$ $0.87 \mu \mathrm{m}$, while samples treated for $6 \mathrm{~h}$ showed $\mathrm{Ra} 1.09 \mu \mathrm{m}$ and Sa $1.09 \mu \mathrm{m}$. Experimental investigations between 4 weeks and 1 year after implant showed clear evidence that the bone response of moderately rough surfaces (Sa between 1.0 and $1.5 \mu \mathrm{m}$ ) was significantly better than bone responses for smoother surfaces ${ }^{23,24}$. The moderately rough implant surfaces promote the differentiation of osteoblastic cells in vitro and achieve a faster and stronger osseous-integration in vivo ${ }^{25}$.

\section{Contact angle}

Results showed an important reduction in the contact angle by the action of carbonitriding. The average value of $84^{\circ}$ for machined samples was reduced to $38^{\circ}$ and $30^{\circ}$ for samples treated for $3 \mathrm{~h}$ and $6 \mathrm{~h}$, respectively. Figure 4 shows the profile of the water drop on the surface of those samples.

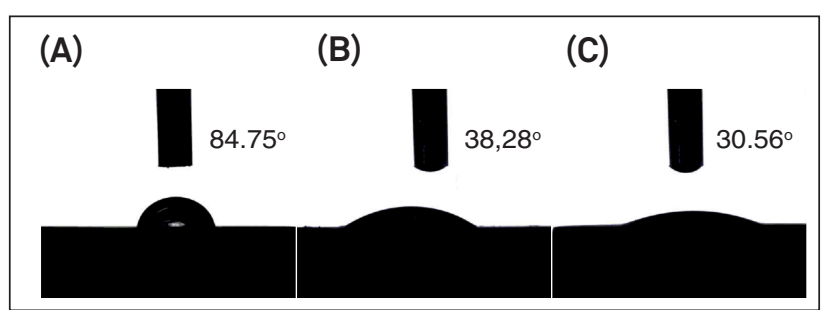

Figure 4: Profile of drop of water on the surface: $(A)$ machined, $(B)$ N49_3, and (C) N49_6.

\section{CONCLUSION}

This study evaluated the surface characteristics of Ti6Al4V after plasma carbonitriding. The carbonitrided samples showed on their surfaces $\mathrm{TiN}_{2}$ and $\mathrm{Ti}_{3} \mathrm{~N}_{1.29}$ phases; the presence of $\mathrm{TiO}_{2}$ or $\mathrm{TiC}$ phases was not observed. The carbonitriding of Ti6Al4V alloy increases the roughness and decreases the contact angle of
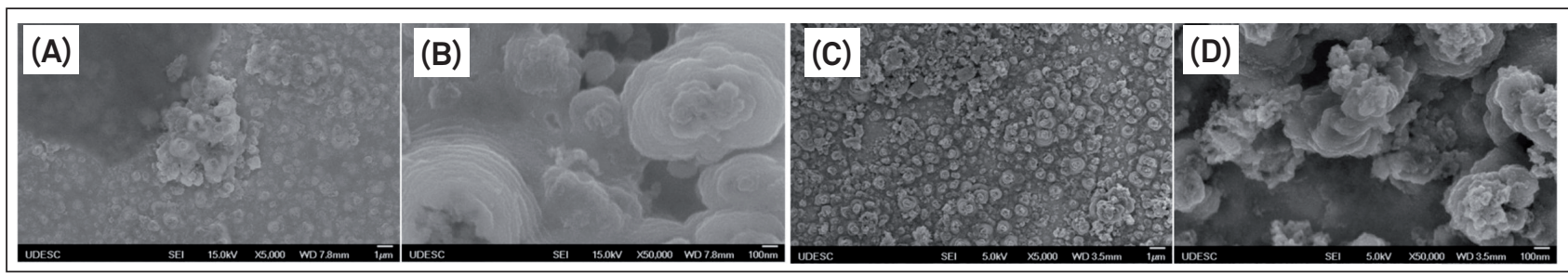

Figure 3: FE-SEM images of nitriding samples: (A) and (B) N49_3 [5000 ×, $50000 \times]$, (C) and (D) N49_6 [5000 ×, $50000 \times$ ]. 
de-ionized water drops. The surface morphology was changed by the action of ion bombardment, which produces nano-holes and micro-roughness. These are some properties related to the biological response of the surface. The low contact angle helps in the contact blood clot - implant surface, which will trigger the whole cascade of events (coagulation, formation of fibrin network, etc.) that interfere with the early stages of healing. The nanostructured morphology increases adhesion of proteins responsible for migration and attachment of osteoblastic cells.

\section{REFERENCES}

1. Man HC, Zhao NQ, Cui ZD. Surface morphology of a laser surface nitrided and etched Ti-6Al-4V alloy. Surface and Coatings Technology. 2005;192(2-3):341-346. https://doi.org/10.1016/j. surfcoat.2004.07.076

2. Fernandes AC, Vaz F, Ariza E, Rocha LA, Ribeiro ARL, Vieira AC, et al. Tribocorrosion behaviour of plasma nitrided and plasma nitrided + oxidised Ti6Al4V alloy. Surface and Coatings Technology. 2006;200(2223):6218-6224. https://doi.org/10.1016/j.surfcoat.2005.11.069

3. Surowska B, Bieniaś J. Composite layers on titanium and Ti6Al4V alloy for medical applications. Journal of Achievements in Materials and Manufacturing Engineering. 2010;43(1):162-169

4. Kieswetter K, Schwartz Z, Hummert TW, Cochran DL, Simpson J, Dean DD, et al. Surface roughness modulates the local production of growth factors and cytokines by osteoblast-like MG-63 cells. J Biomed Mater Res. 1996;32(1):55-63.

5. Raines $A L$, Olivares-Navarrete $R$, Wieland $M$, Cochran $D L$, Schwartz Z, Boyan BD. Regulation of angiogenesis during osseointegration by titanium surface microstructure and energy. Biomaterials. 2010;31(18):4909-4917. http://doi.org/10.1016/j. biomaterials.2010.02.071

6. Buser D, Schenk RK, Steinemann S, Fiorellini JP, Fox CH, Stich H. Influence of surface characteristics on bone integration of titanium implants. A histomorphometric study in miniature pigs. J Biomed Mater Res. 1991;25(7):889-902. http://doi.org/10.1002/jbm.820250708

7. Cochran DL, Schenk RK, Lussi A, Higginbottom FL, Buser D. Bone response to unloaded and loaded titanium implants with a sandblasted and acid-etched surface: a histometric study in the canine mandible. J Biomed Mater Res. 1998;40(1):1-11.

8. Cochran DL. A comparison of endosseous dental implant surfaces. J Periodontol. 1999;70(12):1523-1539. http://doi.org/10.1902/ jop.1999.70.12.1523

9. Cochran DL, Buser D, ten Bruggenkate CM, Weingart D, Taylor TM, Bernard JP, et al. The use of reduced healing times on ITI implants with a sandblasted and acid-etched (SLA) surface: early results from clinical trials on ITI SLA implants. Clin Oral Implants Res. 2002;13(2):144-153

10. Gittens RA, McLachlan T, Olivares-Navarrete R, Cai $Y$, Berner S, Tannenbaum R, et al. The effects of combined micron-/submicronscale surface roughness and nanoscale features on cell proliferation and differentiation. Biomaterials. 2011;32(13):3395-3403. https://doi. org/10.1016/j.biomaterials.2011.01.029

11. Mendonça G, Mendonça DBS, Aragão FJL, Cooper LF. The combination of micron and nanotopography by $\mathrm{H}_{2} \mathrm{SO}_{1} / \mathrm{H}_{2} \mathrm{O}_{2}$ treatment and its effects on osteoblast-specific gene expression of hMSCs. J Biomed Mater Res A. 2010;94A(1):169-179. https://doi.org/10.1002/ jbm.a.32701
12. Tsukimura N, Ueno T, Iwasa F, Minamikawa H, Sugita Y, Ishizaki K, et al. Bone integration capability of alkali- and heat-treated nanobimorphic Ti-15Mo-5Zr-3Al. Acta Biomaterialia. 2011;7(12):4267-4277. https:// doi.org/10.1016/j.actbio.2011.08.016

13. Orsini G, Piattelli M, Scarano A, Petrone G, Kenealy J, Piattelli A, et al. Randomized, controlled histologic and histomorphometric evaluation of implants with nanometer-scale calcium phosphate added to the dual acidetched surface in the human posterior maxilla. J Periodontol.2007;78(2):209-218. https://doi.org/10.1902/ jop.2007.060297

14. Collaert B, Wijnen L, De Bruyn H. A 2-year prospective study on immediate loading with fluoride-modified implants in the edentulous mandible. Clin Oral Implants Res. 2011;22(10):1111-1116. https://doi. org/10.1111/j.1600-0501.2010.02077.x

15. Gittens RA, Scheideler L, Rupp F, Hyzy SL, Geis-Gerstorfer J, Schwartz Z, Boyan BD. A review on the wettability of dental implant surfaces II: biological and clinical aspects. Acta Biomaterialia. 2014;10(7):2907-2918. https://doi.org/10.1016/j.actbio.2014.03.032

16. Chu PK, Chen JY, Wang LP, Huang N. Plasma-surface modification of biomaterials. Materials Science and Engineering R. 2002;36(56):143-206. https://doi.org/10.1016/S0927-796X(02)00004-9

17. Fouquet $\mathrm{V}$, Pichon $\mathrm{L}$, Drouet $\mathrm{M}, \mathrm{Straboni}$ A. Plasma assisted nitridation of Ti-6Al-4V. Applied Surface Science. 2004;221(1-4):248-258. https://doi.org/10.1016/S0169-4332(03)00889-4

18. Farokhzadeh K, Qian J, Edrisy A. Effect of SPD surface layer on plasma nitriding of Ti-6Al-4V alloy. Materials Science and Engineering A. 2014;589:199-208. https://doi.org/10.1016/..msea.2013.09.077

19. Serro AP, Completo C, Colaço R, Santos F, Lobato da Silva C, Cabral JMS, et al. A comparative study of titanium nitrides, TiN, TiNbN and TiCN, as coatings for biomedical applications. Surface and Coatings Technology. 2009;203(24):3701-3707. https://doi.org/10.1016/j. surfcoat.2009.06.010

20. Li G, Xia LF. Structural characterization of $\mathrm{TiC}_{\mathrm{x}}$ films prepared by plasma based ion implantation. Thin Solid Films. 2001;396(1-2):1622. Available from: https://doi.org/10.1016/S0040-6090(01)01227-5

21. Silva SLR, Kerber LO, Amaral L, Santos CA. X-ray diffraction measurements of plasma-nitrided Ti-6Al-4V. Surface and Coatings Technology. 1999;116-119:342-346. https://doi.org/10.1016/S02578972(99)00204-2

22. Davies JE. Understanding peri-implant endosseous healing. Journal of Dental Education. 2003;67(8):932-949.

23. Wennerberg A, Albrektsson T, Andersson B. An animal study of c.p. titanium screws with different surface topographies. J Mater Sci. Mater Med. 1995;6(5):302-309. https://doi.org/10.1007/BF00120275

24. Wennerberg A, Albrektsson T, Andersson B. Bone tissue response to commercially pure titanium implants blasted with fine and coarse particles of aluminium oxide. Int J Oral Maxillofac Implants. 1996;11(1):38-45

25. lezzi G, Degidi M, Scarano A, Perrotti V, Piattelli A. Bone response to submerged, unloaded implants inserted in poor bone sites: a histological and histomorphometrical Study of 8 titanium implants retrieved from man. Journal of Oral Implantology. 2005;31(5):225-233. https://doi.org/10.1563/1548-1336(2005)31[225:BRTSUI]2.0.CO;2 